\title{
Case report on the coincidence of retroperitoneal dedifferentiated giant liposarcoma and renal papillary cell carcinoma
}

\author{
Retroperitoneal dev dediferansiye liposarkom ve renal papiller hücreli karsinomun birlikte \\ görüldügü olgu sunumu
}

Barış ÖZCAN, Metin ÇEVENER, Akın YILDIZ, Mustafa ÖZDOĞAN, Okan ERDOĞAN

\begin{abstract}
The most common histological type of retroperitoneal sarcomas is liposarcoma. Renal papillary cancers account for approximately $10 \%$ of all known renal cell cancers and nephrectomy is the preferred choice for the treatment in suitable cases. In this report, we presented a concurrency of giant retroperitoneal liposarcoma and renal papillary cancer in a 61-year-old male patient. He was referred to our clinic with complaints of abdominal distension and pain. Computed tomography (CT) scan, magnetic resonance imaging (MRI) and positron emission tomography-computed tomography (PET-CT) revealed a giant mass filling intraabdominal and retroperitoneal space, approximately $50 \times 30 \mathrm{~cm}$ in size and also a separate mass which is $6 \mathrm{x} 8 \mathrm{~cm}$ in size in the upper pole of the left kidney. The giant mass was excised in two separate pieces. After frozen section procedure, nephrectomy was performed for mass arising from the left kidney. Histopathological analysis of the large masses, revealed dedifferentiated liposarcoma and renal papillary cellular cancer in the abdomen and left kidney, respectively.

In conclusion, a second primary tumor can be seen in patients with giant retroperitoneal liposarcoma and coincidence of these tumors must be determined in the preoperative period for appropriate treatment.
\end{abstract}

Keywords: Retroperitoneum, Liposarcoma, Renal papillary cancer

Barış Özcan (可), Okan Erdoğan

General Surgery Clinic, Medstar Antalya Hospital, Antalya, Turkey

e-mail: barisozcan2004@yahoo.com

Metin Çevener

Radiology Clinic,Medstar Antalya Hospital, Antalya, Turkey

Akın Yıldız

Nuclear Medicine Clinic, Medstar Antalya Hospital, Antalya, Turkey

Mustafa Özdoğan

Medical Oncology Clinic, Medstar Antalya Hospital, Antalya, Turkey

Submitted / Gönderilme: 09.10.2016

Accepted/Kabul: 02.12.2016
ÖZ

Retroperitoneal sarkomların en sık görülen histolojik tipi liposarkomdur. Renal papiller kanserler renal hücreli kanserlerin $\% 10$ 'unu oluştururlar ve nefrektomi ile tedavi edilirler. Biz burada, retroperitoneal dev liposarkom ve renal papiller kanserin birlikte görüldüğü nadir bir olguyu sunduk.

Altmış bir yaşında erkek hastada karında şişlik ve ağrı şikayeti nedeni ile yapılan tetkiklerinde retroperitoneal alanı ve karın içini dolduran yaklaşık 50x30 $\mathrm{cm}$ boyutlarında liposarkomla uyumlu kitle ve ayrıca sol böbrek üst polde $6 \times 8 \mathrm{~cm}$ 'lik ayrı bir lezyon tespit edildi. Operasyonda biri yaklaşık 40x35cm, diğeri 30x20 cm olmak üzere iki parça halinde dev kitle eksize edildi. Sol böbrekten kaynaklanan kitleden intraoperatif biopsi alınarak frozen inceleme yapıldı. Malign olması nedeni ile sol nefrektomi yapıldı. Dev kitlenin histopatolojik incelemesinde dediferansiye liposarkom olduğu ve sol nefrektomi materyalinde de renal papiller hücreli kanser olduğu raporland. Retroperitoneal dev liposarkom vakalarında eşzamanlı ikinci primer tümörlerin görülebileceği, bunların ameliyat öncesi tetkiklerle tespitinin yapılıp tedavi edilmesi gerekliliği akılda tutulmalıdır.

Anahtar kelimeler: Retroperiton, Liposarkom, Renal papiller kanser

\section{Introduction}

Retroperitoneal sarcomas are rare tumors that account for $15 \%$ of all soft tissue sarcomas. The most common histological type is liposarcoma (41\%) [1]. Because of its characteristic deep location, retroperitoneal liposarcomas are difficult to be diagnosed. While intra-abdominal mass effects are the most common symptoms present in $80 \%$ of patients, pain is the second common symptom [2]. Computed tomography (CT) scan, magnetic resonance imaging (MRI) and positron emission tomography-computed tomography (PET-CT) are diagnostic examinations with unique findings [3]. The gold standard for the treatment is surgery [1]. On the other hand, renal papillary cancer (RPC) accounts for $10-15 \%$ of all types of renal cell cancers and it is the second common type. The primary treatment of RPC is nephrectomy [4]. 
Because of increasing number of PET-CT examinations in the recent years, a significant higher incidence of second primary cancers has been observed. A second primary tumor on the left kidney with retroperitoneal giant liposarcoma has been simultaneously observed in our patient in PET-CT examination for staging. After surgery, in pathologic specimens, renal papillary cancer was diagnosed with dedifferentiated giant liposarcoma.

\section{Case Report}

A 61-year-old male patient who had previously been examined in another medical center with the complaints of abdominal discomfort and pain admitted to our centre. $\mathrm{CT}$ and subsequent PET-CT scan revealed a mass in the abdomen corresponding to a liposarcoma which has heterogeneous, calcified and solid components with fat density. It was approximately $50 \times 30 \mathrm{~cm}$ in size expanding from all retroperitoneal space to the anterior abdominal wall (Fig.1a). Also, another mass, measured about $6 \times 8 \mathrm{~cm}$, was seen in the upper pole of left kidney (Fig.1b).

Percutaneous core-biopsy result of the giant mass was liposarcoma. In the surgical exploration, a giant mass filling the whole retroperitoneum, covering both kidneys and invading right colon was seen. This mass was removed as

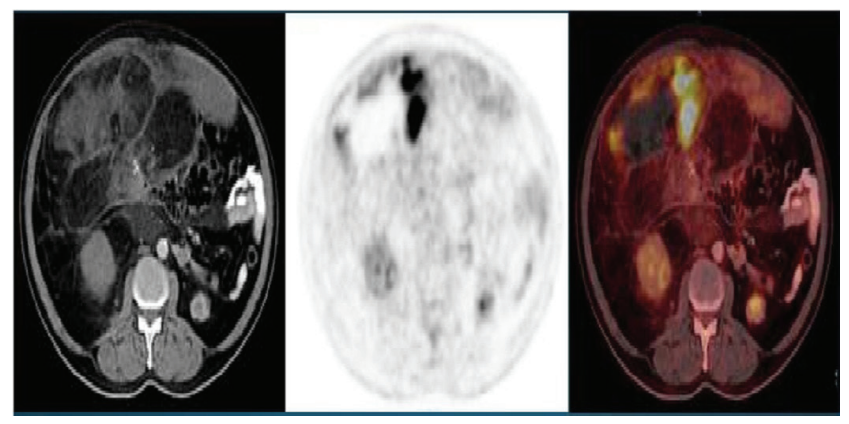

Figure 1a. CT and PET-CT scans of the giant liposarcoma

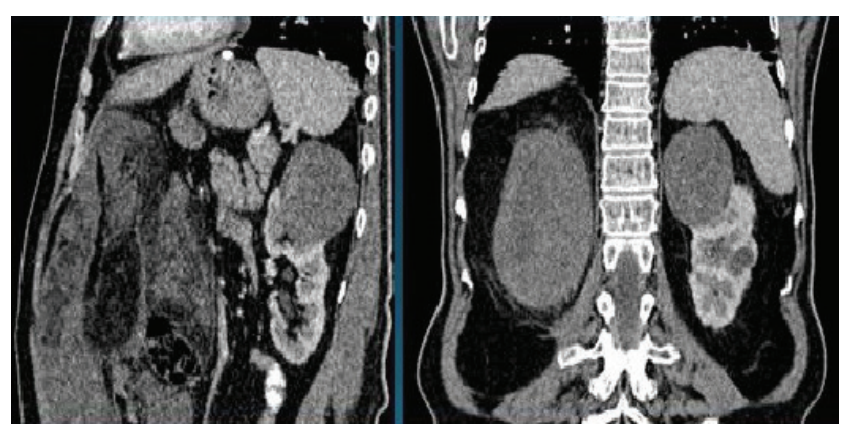

Figure 1b. CT and PET-CT scans of the left renal mass two separate pieces which were approximately $40 \times 35 \mathrm{~cm}$ and 30x20 cm in size. Right hemicolectomy was performed with the right kidney preservation (Fig.2a-2b).

Frozen section biopsy analysis of the tumor in the left kidney revealed malignancy. Left kidney nephrectomy was performed. Two pieces of giant soft tissue masses which were $14 \mathrm{~kg}$ in total were defined as dedifferentiated liposarcomas in histopathological examination (Fig.3). Left nephrectomy material, measured $4 \times 3 \mathrm{~cm}$, was reported as renal papillary cell cancer (Fig.4).

The patient was discharged without any complaint. Six months after the first surgery, follow-up CT scan showed a $7 \times 5 \mathrm{~cm}$ intra-abdominal mass in the periumbilical region. It was accepted as recurrence and the patient was operated again.

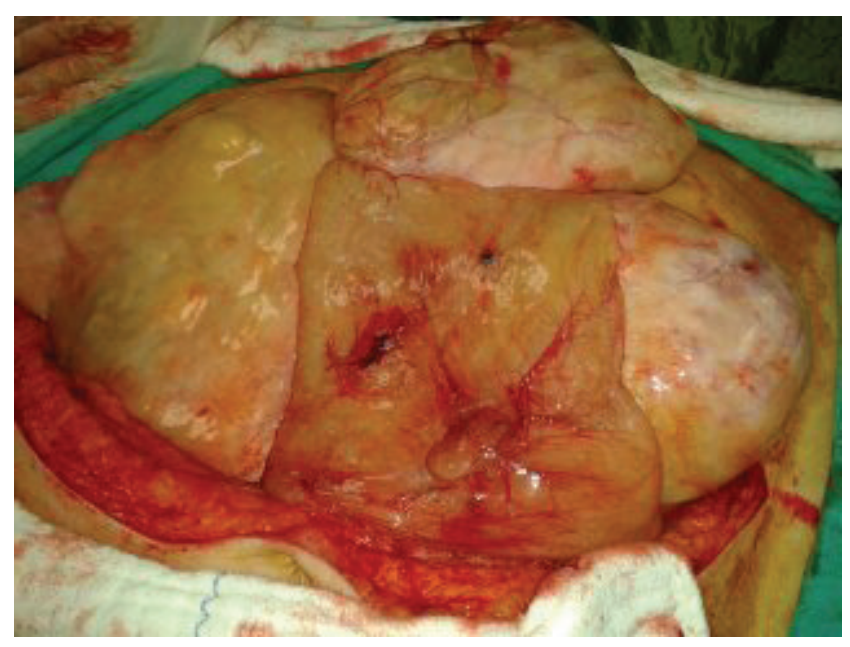

Figure 2a. Intra-operative macroscopic view of the mass

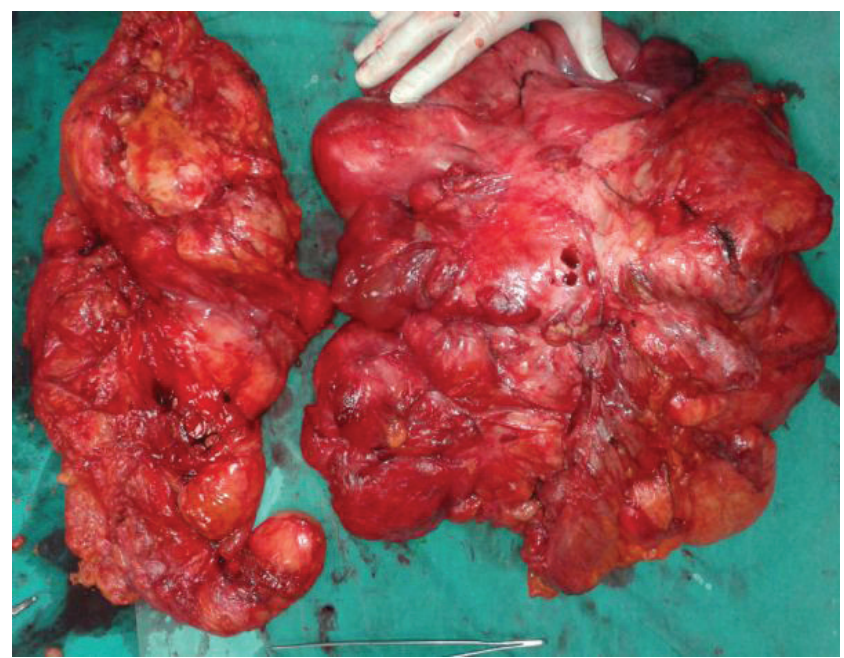

Figure 2b. Post-operative macroscopic view of the mass 


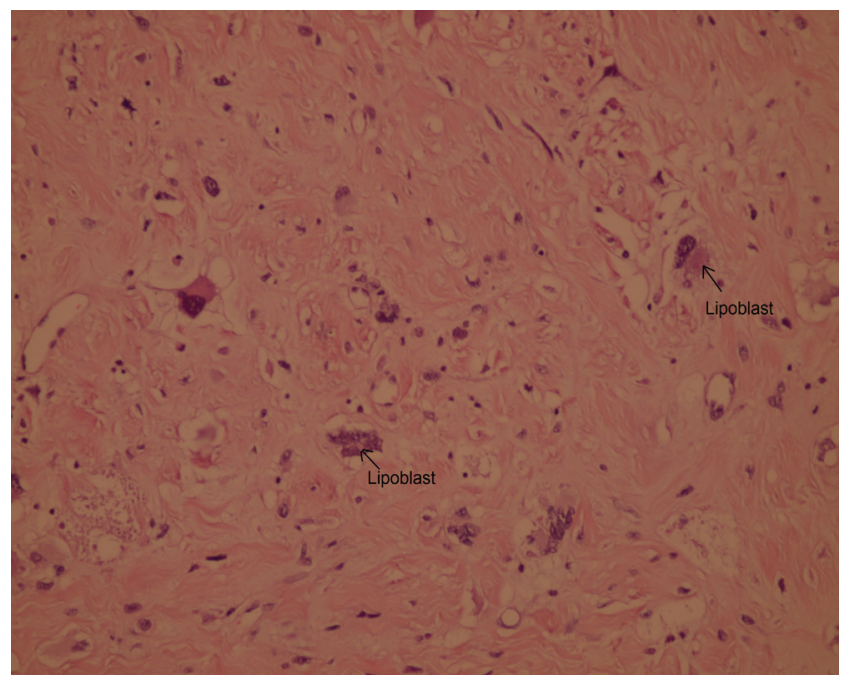

Figure 3. The microscopic view of the dedifferentiated liposarcoma

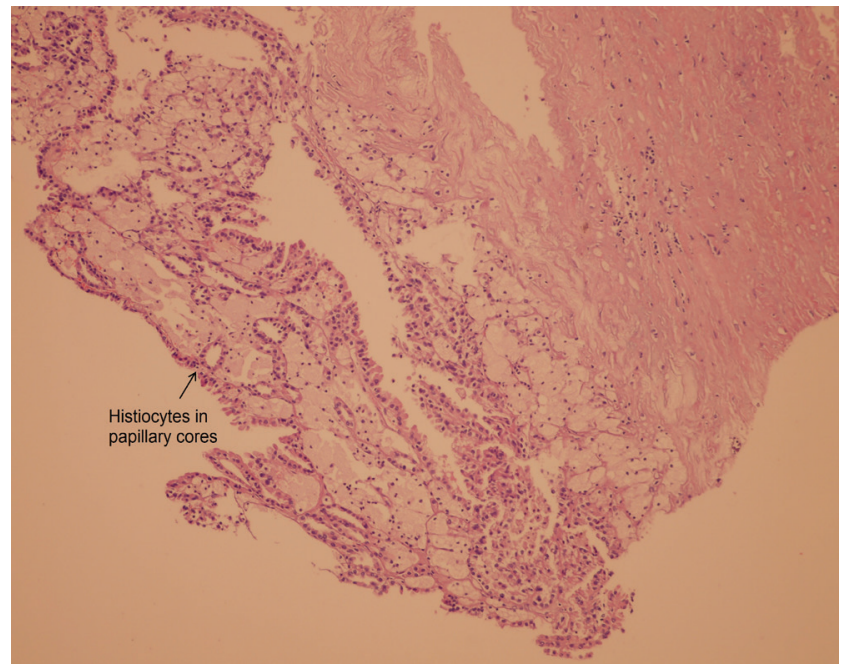

Figure 4. The histopathological view of the renal papillary cancer

\section{Discussion}

With a rate of $41 \%$, liposarcoma is the most common histological type of retroperitoneal sarcomas [1]. This is followed by leiomyosarcoma (28\%), malignant fibrous histiocytoma (7\%) and fibrosarcoma (6\%). Liposarcomas originate from mesoderm and are differentiated from the adipose tissues [5]. Liposarcomas account for 10-14 \% of all soft tissue sarcomas and $85 \%$ of them are malignant [6]. They are seen more frequently in males and 5th and 6th decades of life [2,7]. Our patient is male and 61 years old.

The well-differentiated liposarcoma has the best clinical course. The worst clinical outcome is defined in the poor differentiated liposarcomas. Dedifferentiated liposarcoma is defiined as "to express the poorly differentiated sarcoma adjacent to well-dedifferentiated liposarcoma". Dedifferentiated liposarcoma is a highgrade sarcoma with more malignant and aggressive course seen in older ages [3]. The vast majority are located in the retroperitoneum. Histological type of the tumor, its location, age older than 50, tumors larger than $10 \mathrm{~cm}$, microscopically positive surgical margins and presence of local recurrence are among poor prognostic criterias [1]. Local recurrence and distant metastasis are $41 \%$ and $17 \%$, respectively. Distant metastases can be seen in the lungs, liver, brain, and bones.

Because of their location, the retroperitoneal sarcomas are generally asymptomatic. The most common symptoms are abdominal pain, abdominal swelling or palpable mass [2]. Our patient was admitted to our hospital with the complaints of swelling and pain in the abdomen. All his symptoms occurred in the last few months.

Computed tomography, MRI, and PET-CT are consecutive examinations in diagnosis in order to define tumor size, its localization and/or in determining metastatic lesions [3]. In our study, besides the CT scan, PET-CT imaging was also performed in our hospital. PET-CT findings showed, hypometabolic parts in some areas of the tumor and hypermetabolic parts in other areas, and various SUV-max values in different areas showed different biological properties. Histopathological examination results of different differentiated areas of the tumor, supported the PET-CT scan findings.

Liposarcomas are slow-growing tumors. Because of retroperitoneal location they show symptoms in a late period. At the time of diagnosis, $20 \%$ of these tumors are detected when they become larger than $10 \mathrm{~cm}$, with an average diameter of $20-25 \mathrm{~cm}$ and an average weight of $15-20 \mathrm{~kg}[1,6]$. Only, a few cases larger than these sizes have been published in the literature $[2,6]$. In our case, a giant liposarcoma with an approximate total size of $50 \times 30 \mathrm{~cm}$ was excised in two pieces - one measured $41 \times 35 \times 15 \mathrm{~cm}$ in size and the other measured as $33 \times 21 \times 12$ $\mathrm{cm}$. The total weight of the tumor was $14 \mathrm{~kg}$.

Liposarcomas are chemo-resistant tumors. As the toxic effects are widely observed in the extensive implementation of radiation therapy, surgery is the gold standard for the treatment $[1,7]$. In surgery, in order to achieve tumor-free surgical margins, kidneys, ureters or colon can be resected if any of them are invaded by the tumor. In our case, the tumor has encased the right 
kidney and the ascending colon. As a left nephrectomy operation was performed, the right kidney was protected by dissecting only the tumor, and the giant masses were removed with right hemicolectomy.

Like liposarcomas, renal papillary cancers are also seen more frequently in males and in the 6th and 7th decades of life [4]. They are also tumors that are resistant to chemotherapy and radiation therapy, that is why they are treated with nephrectomy $[4,8]$. In our case, frozen section technique was also applied for kidney tumor. After the malignant result of frozen section, left nephrectomy was performed.

\section{Conclusion}

Coincidence of liposarcoma and renal cancer is quite rare in the literature [8]. It should be considered that in patients with retroperitoneal giant liposarcoma, the second primary tumors such as renal cell cancers might also be seen. Detection of coincidence in pre-operative examinations can allow simultaneous treatment in surgery.

\section{References}

1. Lewis JJ, Leung D, Woodruff JM, Brennan MF. Retroperitoneal soft-tissue sarcoma: analysis of 500 patients treated and followed at a single institution. Ann Surg 1998;228:355-65.

2. Morandeira A, Prieto J, Poves I, Cano JJS, Diaz C, Baeta E. Giant retroperitoneal sarcoma. Can J Surg 2008; 51:E79-E80.

3. Tateishi U, Hasegawa T, Beppu Y, Satake M, Moriyama N. Primary dedifferentiated liposarcoma of the retroperitoneum: Prognostic significance of computed tomography and magnetic resonance imaging features. J Comput Assist Tomogr 2003;27:799-804.

4. Kovacs G, Akhtar M, Beckwith BJ, et al. The Heidelberg classification of renal cell tumors. J Pathol 1997;183:131-3.

5. Hassan I, Park SZ, Donohue JH, et al. Operative management of primary retroperitoneal sarcomas. A reappraisal of an institute experience. AnnSurg 2004;239:244-50.

6. Echenique-Elizondo M, Amodarain Arratibel JA. Liposarcoma retroperitoneal gigante. Cir Esp 2005;77: 293-5.

7. Nijhuis P HA, Sars P RA, Plaat BEC, Molenaar WM, Sluiter WJ, Hoekstra HJ. Clinico-pathological data and prognostic factors in completely resected AJCC Stage I-III Liposarcomas. Ann Surg Oncol 2000;7:535-43.

8. Williamson JML, König TC, Canelo R. Incidental finding of renal cell carcinoma in recurrent retroperitoneal liposarcoma. Ann R Coll Surg Engl 2008;90:4-5. doi: $10.1308 / 147870808 X 257157 b$ 